\title{
A New Sacramental Theology for e-Eucharist?
}

Mattijs Ploeger

\section{Abstract}

During the 2020-21 COVID-19 crisis, participation in the eucharist was largely reduced to watching a service on television or online. This article focuses on whether such a form of participation in the eucharist - perhaps enhanced by taking some bread and wine individually in front of the screen - could be called sacramental participation from the point of view of a (broadly Catholic) systematic sacramental theology. I argue that a spiritual form of real presence is possible by virtue of Christ's omnipresence, but that sacramental presence is inevitably dependent on embodiment and locality.

\section{Keywords}

Online worship, sacramental theology, eucharist, incarnation, embodiment, local church

\section{Introduction: limitations on eucharistic participation}

I first became aware of the fact that not all people who wish to attend church are able or allowed to do so when I encountered the hagioscope in the medieval parish church of my youth. ${ }^{1}$ At the time the church was built, lepers - who were excluded from usual social contacts and, as part of that, were not allowed to enter the church - could watch the elevation of the host after the consecration by looking through the hagioscope, a small hole in the wall near the altar. Notwithstanding the important fact that lepers could not mingle with the churchgoers, the limitation of their participation in the eucharist must not be exaggerated, as most of the late-medieval congregation would have participated in the same way: by watching the host, adoring Jesus Christ and having 'spiritual communion' with him. ${ }^{2}$

Another example of refraining from church attendance while still, in some way, feeling part of a wider Christian fellowship was provided by my grandfather. His conservative mindset could not cope with the leftish content he detected in sermons and prayers of many ministers of the Netherlands Reformed Church in the 1970 s and 1980s. So he switched from being an active church member to watching services on television. The advantage of this way of worshipping was the presence of an on/off

1) Cf. M.A. Vrijlandt, De hervormde Werenfried-kerk te Westervoort (Zutphen: Walburg Pers, 1979), 7. The gothic chancel with the hagioscope was added to the twelfth-century church in the fourteenth century.

2) See the article by Ineke Cornet in this volume. 
button, which was - in our family famously - employed after a preacher said a prayer of thanksgiving for the life of social-democrat prime minister Joop den Uyl. Before the final blessing, my grandfather switched off the TV with the solemn words, "In that blessing I do not wish to be included." Apart from the funny side of the story, it shows that he felt 'included' in the televised service - for better or worse.

When I became a parish priest in the Old-Catholic Church, I gained even more experience with people who wanted to go to church and participate in the eucharist but were unable to do so. In the Catholic tradition, bringing communion to people in their home or in hospital is a well-known way of letting them participate in the worship that has taken place in church. Although it is possible to celebrate a complete eucharistic service with people at home, the most usual way of giving communion to people at home or in hospital is by extending the liturgical moment of communion: they receive the body of Christ in the form of a host that was part of the celebration in church. Any remaining consecrated hosts are kept in the tabernacle after the eucharistic service; from there, they can be administered to people outside the church. In a small parish, I used to increase this sense of their being part of the same service by (sometimes) mentioning - before the final blessing - the names of those to whom I was to bring these specific hosts, which I had visibly set apart in a small pyx. In doing so, I intended to make the congregation aware of the absentees' invisible but real participation in the same celebration, just as those who received communion at home were aware that the host was coming from the service in church.

Finally, I can mention my own experience with 'spiritual communion' in a twofold way. As a student, I regularly attended weekday masses in a Roman Catholic church. Respecting Roman Catholic rules, I refrained from receiving communion, the result being that I had years of experience with spiritual communion. A different situation, though one also resulting in spiritual communion, is my occasional role as an amateur organist. I prefer to play a piece of organ literature during communion, instead of having a substantial period of silence while I make my way downstairs and through the aisle up to the communion rail. I only add these personal experiences in order to illustrate the many ways that I have experienced 'non-communicating attendance' at a eucharistic service. It does not hamper my feeling of being part of the service, part of the congregation, and having communion with Christ, although it can induce a 'longing' for receiving communion physically. ${ }^{3}$

\footnotetext{
3) Ton van Eijk, Eucharistie. Het woord en het brood (Bergambacht: 2VM, 2010), 137-65 offers a wellthought proposal for a spiritual attitude for those who do not physically communicate during a eucharistic service. The proposal is based upon Christ's presence in the Word, the unity of Word and Sacrament, and the pneumatological character of both physical and spiritual communion. Only insofar as the difference between physical and spiritual communion seems somewhat to disappear in Van Eijk's account, I have some reservations about it, in view of section 5.1 below.
} 


\section{No new issues, but hidden issues brought to light}

The preceding introduction serves to explain my surprise at the fact that church ministers and theologians seem to regard the 2020-21 COVID-19 pandemic - particularly the fact that people are not allowed to physically attend church and therefore have to participate by television or online - as something which is fundamentally 'new' and which asks for 'new' ways of theologizing. Compared to the many situations in which people throughout the centuries have not been able or allowed to attend church as they would have wanted to, the situation under coronavirus-related measures can hardly be seen as 'new'. It may be new for a healthy, middle-aged preacher or priest - but it wasn't new for a medieval leper, and it isn't new for a significant number of our own parishioners who are temporarily or permanently house-bound. And as the example of my grandfather shows, it is not new for people who feel ambivalent about their ecclesial affiliation to remain in contact with a church through televised or online services. What gives the impression of novelty is that an exceptional situation is temporarily imposed on the majority of Christians rather than on a minority. But its exceptional character remains, so that in systematic-theological terms no fundamentally 'new' situation has occurred.

Instead of calling the situation new, I would rather say that living under the coronavirus measures has brought to light a number of issues that would otherwise have remained relatively unnoticed. In this section I will discuss two attitudes - first of ordained minsters, then of parishioners generally - which I think have surfaced in these unusual circumstances. After that, in section 3, I will reflect on whether it is appropriate to make liturgical-theological comments about things that happen in a crisis situation. The rest of the article, from section 4 onwards, will deal with the main question: Do we need 'new' sacramental-theological thought because of what could be termed e-eucharist - televised or online eucharist? ${ }^{4}$

The first issue I wish to discuss is the slight 'clericalist' bent in some church ministers, who experienced a kind of identity crisis as soon as the liturgical part of their ministry was suspended. "What can I do?" was the desperate question, revealing somewhat of an 'activist' understanding of their role. My answer would be (and has been, to those who asked me): being pastorally available to their parishioners over telephone or digital means or social media; praying for their parishioners, as well as for victims of the pandemic; taking a comforting attitude toward their church council or other active church members; making their parishioners realize this is not the end of the world, but rather a period in which church life continues (though in limited and partly different ways); using their extra time to catch up on administrative business or attend to their own spiritual life. That is quite a lot of 'priestly' work, which, indeed, temporarily does not include any liturgical presiding. What does it tell us about

4) I thank Louis Runhaar and Peter-Ben Smit, Old Catholic priests who currently work in a parish and in academia respectively, for sharing their reflections on these topics with me. 
a priestly (or otherwise ordained ministerial) identity ${ }^{5}$ when it proves difficult to become 'just' one of the church members who digitally attend - to take the example of my own church - the bishops' weekly online eucharist?

Another issue has come to light by the reaction of some parishioners to the suspension of physical eucharistic communion. Their reaction seems not to be "It's a pity that we have to hold a eucharistic fast for some time, but let's make the best of it," but rather "How can we avoid eucharistic fasting?" Some parishioners answer the latter question by taking some bread (and wine) at home while watching a televised or online eucharistic service. Does not such a practice reveal an individual, a largely 'displaced' and de-ritualized understanding of what it means to participate in eucharistic communion, rather than regarding communion as an integral part of the communal eucharistic ritual? ${ }^{6}$ Perhaps one could even go so far as to see this phenomenon as a reflection of a consumer mentality: it could be an example of the expectation that every (in this case spiritual) wish will immediately be fulfilled. The need for a temporary eucharistic fast, ${ }^{7}$ and the solidarity that comes with it, could be a healthy corrective of a lifestyle that assumes the unlimited availability of everything we want to eat, drink, use, and experience.

\section{Hesitations about liturgical-theological comments on crisis management}

Before I go any further, I must make it clear that I intend to leave aside the serious medical and economic aspects - and the personal dramas that accompany these aspects - of the pandemic. I am aware of them, but they are not the subject of this article. I am solely reflecting on some of the liturgical-theological issues that have appeared because of the reality of church life under pandemic-related restrictions. This is only a marginal aspect of the crisis, but it is a real one and it is legitimate to address it.

At the same time, I doubt the legitimacy of a certain kind of theological reflection that started to take place very soon after pandemic-related measures were put into force. By this I mean the sort of theologically and liturgically 'correct' attitude that was employed to criticize some practical solutions offered by church leaders as an immediate and temporary response to the situation with COVID-19. I regard an online article by Albert Gerhards, Benedikt Kranemann, and Stephan Winter as an example

5) Cf. Peter-Ben Smit, ed., Ambt - Spiritualiteit - Roeping. Theologische verkenningen. Met bijdragen van Rebekka Willekes, Marleen Blootens, Jos Moons, Mattijs Ploeger en Wim Dekker (Amersfoort/Sliedrecht: Merweboek, 2018).

6) Perhaps the practice could be investigated as an instance of 'ritual failure', as the term is employed in ritual studies.

7) The phrase 'eucharistic fast' is not used here in its traditional meaning of abstaining from ordinary food before receiving communion, but is somewhat creatively used in the sense of abstaining from communion itself. 
of this. ${ }^{8}$ I am sorry to say this, because the authors are well-respected Roman Catholic professors of liturgical studies at German universities. The validity of their theological and liturgical arguments is beyond critique, as they argue against the 'private mass' (Privatmesse), which is - according to them - promoted by some Roman Catholic dioceses in Germany. And in a specific Roman Catholic context but not necessarily outside that context - it is also understandable that they deplore the exposition of the Sacrament or processions with the Sacrament. What I, nevertheless, protest against is the timing of such an article and its tone.

As to the article's timing, it makes the authors vulnerable to the charge that they apply an approach, based on long-term study, to an emergency situation in which short-term answers are needed and no one has the perfect solution. Publishing such an article at such a time only widens, in my opinion, the gap between academic learning and church practice. I am usually the last one to suggest a gap between theology and practice, but in this case I am afraid that such an impression is the result of an untimely publication of an otherwise sensible liturgical-theological opinion.

As to the article's tone, the authors use the word 'ghost masses' (Geistermessen) for the allegedly private masses, and they ridicule the idea of a eucharist being celebrated 'vicariously' (stellvertretend) by interpreting it in a medieval way. There may be instances in which the authors are right in both respects. That is, there may be some Roman Catholic priests in Germany who celebrate mass completely on their own (which is the only case in which it is correct to speak of a private mass) and interpret it as vicarious in the medieval sense: namely, that celebrating the eucharist is reduced to a potestas consecrandi, which is the property of the priest alone (seinen ureigenen Besitzstand), such that it is not the whole church celebrating in and for the world, but rather the priest celebrating in the name of Christ to the benefit of the people. These are the practices and interpretations against which the authors argue. And although, as I said, there may be some cases to which they apply, I very much doubt that both these practices and these interpretations are to be found anywhere else than with people in reactionary circles, whom we as liturgical-theological scholars do not take as our point of reference anyway (and who, in their turn, do not give much for our liturgical theology).

Apart from those reactionary circles, in most Roman Catholic cathedrals and parish churches in Germany the eucharist will probably neither be celebrated nor interpreted in such a way. It will rather be celebrated in a small group, including, for example, a lector, cantor, server, and sacristan - which makes it fundamentally different from a private mass. These people will only interpret their liturgy as vicarious insofar as they intend to celebrate this mass as a pars pro toto of the diocesan or parochial congregation. Especially when the mass is broadcast on television or online, with the explicit inten-

8) Albert Gerhards, Benedikt Kranemann, Stephan Winter, "Privatmessen passen nicht zum heutigen Verständnis von eucharistie. Liturgiewissenschaftler kritisieren Anweisungen von Diözesen in Corona-Krise," guest contribution to katholisch.de, March 18, 2020, https://www.katholisch.de/artikel/24874-privatmessenpassen-nicht-zum-heutigen-verstaendnis-von-eucharistie. The German citations in my text (in parentheses) are from this article. 
tion to include the viewers into the celebration, it is simply incorrect to call this a private mass and to explain its vicariousness in a medieval way. ${ }^{9}$

I have reflected on this article by Gerhards, Kranemann, and Winter because, in my opinion, it is an example of correct liturgical-theological reasoning at an untimely moment. From bishops and priests in my church I know how difficult it was in the beginning of the COVID-19 crisis to respond to an emergency and to take quick measures that strike a balance between different priorities. There is, for example, a lot to say about parish priests who want to bless and distribute palm branches without having a Palm Sunday service in which those palm branches are used for a procession. Blessing an Easter Candle without having an Easter Vigil amounts to the same thing. Both are instances of a materialization of liturgy, the transition from communal liturgical act to individualized sacred object (Verdinglichung). ${ }^{10}$ But on the other hand, who would deny the genuine pastoral intention behind the distribution of blessed palm branches to parishioners, who do not suddenly take those branches for talismans, but who feel that the tangible branch connects them to the online Palm Sunday service and thereby to the community of the church to which they belong?

In normal circumstances, I am all for a strong connection between liturgical-theological reasoning and ritual-liturgical practice. But in a crisis, like suddenly having to give shape to church life under pandemic-related measures, I think academic reflection should take a detached stance, give church practice the benefit of the doubt, and start the engagement between theory and practice again when circumstances have stabilized.

\section{Divine presence in front of a screen: real but not sacramental}

With this hesitation in mind, I will now discuss an aspect of sacramental theology that has arisen during the COVID-19 crisis. The question is whether people can sacramentally participate in the eucharist at home by watching a televised or online service and taking bread (and wine) at the moment of communion. Are they, by doing so, 'really participating' in the sacrament? Before this question can be answered, one has to be clear about the meaning of the phrase 'real participation'. In the context of this article I want to distinguish two possible ways of understanding 'real participation': in terms of personal experience and in terms of sacramental reality.

The first possibility is to understand real participation in the sacrament in terms of personal experience. Do I feel connected to the service I'm watching, connected to the people I see on the screen, connected to the people who watch with me, connected to Jesus Christ? It is interesting to see the

9) A good example is the practice in Cologne Cathedral, available at domradio.de.

10) Cf. Mattijs Ploeger, "Sacramentalia: geen heilige dingen, maar participatie in de heilige geheimen," in Geloof dat probeert te begrijpen. Bijdragen tot een oud-katholieke theologische benadering (Amersfoort/ Sliedrecht: Merweboek, 2020), 112-20. 
results of empirical research into such questions. From one Dutch inquiry it can be concluded that regular viewers - especially those who are no longer able to physically attend a service in church - regard the televised service as their real liturgy, or at least as a satisfactory replacement. ${ }^{11}$ Sacramentaltheological considerations are put in their place by the fact that people feel touched by the sermon twice as much as by any other element of the service (hymns, prayers, communion, etc.). ${ }^{12}$ But as one researcher - sociologist and theologian Kees de Groot - wryly remarks, some of the participants took the phrase "What is it that touches you?" (Wat raakt $u$ ) to mean "What is it that irritates you?"13 Perhaps there is still hope for something else than the sermon.

It is not the task of a systematic theologian to argue with the personal experience of participants in the liturgy. Nor is this article the place to further reflect on the possible tension between individual religious experiences and the communal ecclesial character of liturgy and sacraments. ${ }^{14}$ If people would take bread (and wine) individually in the course of a service they are watching and find that they experience communion with Christ and/or with the online community, this can be interpreted theologically as an instance of divine omnipresence. The service that is being watched, and the bread that is being taken, can serve as a focus that enhances the experience of divine presence, in the same way in which a lighted candle or a religious image can function as a focus of prayer. This presence of God, Jesus Christ, the Holy Spirit, is both experientially and theologically real. The question is, however, whether it is sacramental presence in the particular way in which the Christian faith understands sacramentality.

Therefore, the second way of understanding the word 'real participation' is to interpret it sacramentally. Even within a broad understanding of sacramentality, ${ }^{15}$ baptism and the eucharist are the central foci in which sacramentality (the transparency of the world towards God) becomes tangible. In this respect, the question no longer needs to be phrased as "Do I feel connected to what I am watching?" but "Is this real experience of divine presence a sacramental experience?" In my opinion, this

11) Kees de Groot, "Vieren via de televisie" in God in je huiskamer, ed. Hein Blommestijn et al. (Kampen: Kok and KRO/RKK Mediapastoraat, 2006), 29-30, 39.

12) De Groot, 31.

13) De Groot, 32.

14) Cf. Mattijs Ploeger, "Kirchlichkeit, Gebundenheit und Freiheit der Liturgie in altkatholischer Sicht," in Gemeinsames Gebet. Form und Wirkung des Gottesdienstes, ed. Luca Baschera, Angela Berlis, and Ralph Kunz (Zürich: TVZ, 2014), 209-29.

15) By a broad understanding of sacramentality I mean the view that sacramentality is constitutive of a Christian world view, rather than holding on to a specific number of sacraments as incidental 'miraculous' moments in an otherwise unsacramental world. Cf., e.g., Hans Boersma, Heavenly Participation: The Weaving of a Sacramental Tapestry (Grand Rapids, MI: Eerdmans, 2011); Mattijs Ploeger, "Een theologie van de sacramentaliteit," in Geloof dat probeert te begrijpen, 62-78. An even wider perspective, slightly more detached from the particular sacraments, is offered in the impressive theological work of David Brown. Cf., e.g., David Brown, God and Grace of Body: Sacrament in Ordinary (Oxford: Oxford University Press, 2007). 
question has to be answered negatively, because Christian sacramentality differs from other Christian religious experiences. In the remainder of this contribution I will argue that Christian sacramentality, however broadly it may be understood, is always marked by embodiment and locality.

\section{Embodiment}

During the coronavirus crisis, a parish priest told me that he had seen some hosts on a saucer next to the computer screen in the home of a parishioner. I took this as an example of the personal experience I described in the previous section, one which should be treated with pastoral sensitivity and theological respect. However, my colleague continued by asking me whether I agreed with him that we need some new thinking on sacramental theology.

This is where my problem, stated in section 2, comes in: the suggestion that COVID-19 has brought us into 'new' territory. The question of whether you fully participate sacramentally in the eucharist by taking a host individually in front of a screen is not a new question. And the answer is no - at least from a Catholic sacramental-theological perspective. I will explain why I think this is the case. (And as I hope to have made clear in section 4 , I do not mean this as a denunciation of anyone's personal - and real - religious experience.)

\subsection{The work of the Holy Spirit is not spiritualization but incarnation}

There is a difference between omnipresence and sacramental presence. As soon as this difference is blurred, sacramental presence ceases to have any specific meaning. Sacramental presence, although 'powered by' the Holy Spirit, is always an embodied presence. To understand the role of the Holy Spirit in the sacraments (the epicletic character of the sacraments) as in some way 'spiritualizing' the sacramental presence is a misunderstanding. According to Karl-Heinz Menke, it is a typically Protestant misunderstanding ${ }^{16}$ - not, I would say, Protestant in a denominational sense, but probably Protestant in a phenomenological sense. The 'Protestant' concept is that after Jesus Christ's ascension his role has been taken over by the Holy Spirit. The role of the incarnation has come to an end: it is now the period of spiritualization. The 'Catholic' concept is the opposite: the role of the Holy Spirit after Christ's ascension is to continue the incarnation in the (broadly conceived) sacramental reality of the church. The Holy Spirit does not take the place of Christ, but brings Christ to us and makes us participants in Christ. ${ }^{17}$ In Menke's words, ${ }^{18}$

16) Cf. Karl-Heinz Menke, Sakramentalität. Wesen und Wunde des Katholizismus (Regensburg: Pustet, 2012).

17) Menke, 24, 29, 122, 130, 184, 283 and passim.

18) Menke, 262. "Der Heilige Geist ist also nicht das pneumatologische im Unterschied zu Jesus Christus als dem inkarnatorischen Prinzip der Kirche, sondern im Gegenteil die Übersetzung der vertikalen Inkarnation des Christusereignisses in die horizontale Inkarnation der Kirche" (emphasis added). 
The Holy Spirit is, therefore, not the pneumatological [principle of the church] in contrast to Jesus Christ as the incarnatory principle of the church, but to the contrary: [the Holy Spirit is] the translation of the vertical incarnation of the Christ event into the horizontal incarnation of the church.

The classic liturgical-theological debate between Gerardus van der Leeuw and Oepke Noordmans in the 1930 s is still relevant for this particular issue. I briefly refer to their discussion, if only in order to prove that the Protestant/Catholic divide is not denominational but phenomenological. ${ }^{19}$ Both Van der Leeuw and Noordmans were theologians in the Netherlands Reformed Church, but Van der Leeuw represents the 'Catholic' stance and Noordmans the 'Protestant' one.

For Noordmans, the Christian faith is best described as a 'message' (boodschap) that has to be proclaimed. All 'forms' (vormen) - liturgical, sacramental, cultural - are broken. “On Calvary all forms and figures perish." ${ }^{20}$ A restoration of forms is only to be expected in the eschaton, which cannot be anticipated. Van der Leeuw, however, has a much more positive view on creation (schepping) and recreation (herschepping). His theology is rooted in the incarnation (which he calls the re-creation) and he views creation from the perspective of the incarnation (whereas Noordmans views creation from the perspective of the fall and the crucifixion). Therefore, Van der Leeuw is able to see God's revelation in earthly forms and figures. He admits that the form of the incarnate One is a broken form - the form of a servant - but it is nevertheless a form. Jesus' kenosis (self-emptying) does not go so far as to evaporate. His form remains. Otherwise, says Van der Leeuw, "we would be left alone in an empty world with a word that could only be sound." ${ }^{21}$ According to Van der Leeuw, the Word has become flesh and remains incarnate - it does not evaporate into a 'word' (without a capital W). Of these two concepts, only Van der Leeuw's concept has room for an incarnated, sacramental understanding of the liturgy and the sacraments.

\subsection{Sacramentality of sound and word?}

It would be interesting to improvise on Van der Leeuw's sacramental theology, such as along the lines set out by Mirella Klomp. Combining Van der Leeuw's sacramental theology with his 'sacramental' view on the arts, ${ }^{22}$ Klomp explores the extent to which 'the sound of worship' (music in different

19) For a more elaborate presentation, including more references to the sources, cf. Mattijs Ploeger, Celebrating Church: Ecumenical Contributions to a Liturgical Ecclesiology (Groningen/Tilburg: Liturgisch Instituut, 2008), 319-33.

20) O. Noordmans, Liturgie (Amsterdam: Holland, 1939), cited in O. Noordmans, Verzamelde werken, vol. 6 (Kampen: Kok, 1986), 94 (“Op Golgotha vergaan alle gestalten en alle vormen”).

21) G. van der Leeuw, Sacramentstheologie (Nijkerk: Callenbach, 1949), 272 ("wij alleen gelaten worden in een lege wereld met een woord, dat slechts klank kan zijn").

22) Cf. Marcel Barnard, De dans kan niet sterven. Gerardus van der Leeuw (1890-1950) herlezen (Zoetermeer: Meinema, 2004). 
styles, silence, exclamations, the performance of the sermon) can be called sacramental. ${ }^{23}$ Worship "becomes incarnational when the performers encounter the living Christ in the fleshly embodiment of their faith." Therefore, when the cultural-anthropological notion of 'embodiment of faith in worship' meets the theological notion of 'incarnational worship', the sound of worship can be called 'sacramental'. ${ }^{24}$ Would this imply that televised or online liturgy could, through its 'sound', become in at least some way sacramental?

A similar question could be asked regarding the sacramentality of the word. Van der Leeuw affirms the sacramentality of the word. Phenomenologically, the word has the power of absolving (vrijspraak) and of lying (leugen) ${ }^{25}$ - one could add cursing and blessing. ${ }^{26}$ Theologically and liturgically, the word takes the form of the absolution of sins, the reading of Scripture, and the sermon. ${ }^{27}$ If the word has this sacramental power, does this also mean that it creates sacramental presence through televised or online worship?

\subsection{The limitations of the mediation of a medium}

Perhaps the ambivalence I feel toward these questions is due to the fact that broadcast liturgy could be called, in the words of Willem Marie Speelman, "the mediation of a medium". ${ }^{28}$ Liturgy is divine/ human mediation; its broadcasting is the mediation of that mediation. This is why questions about broadcast liturgy can become endless - and rather scholastic and casuistic. Papal blessings and indulgences are validly received via television or radio (instrumenti televisifici vel radiophonici), but only by direct transmission at the moment when the blessing is performed (dum peraguntur), not by deferred transmission at a later moment. ${ }^{29}$ Otherwise one could accumulate indulgences by continuously replaying the blessing. ${ }^{30}$

23) Mirella Klomp, The Sound of Worship: Liturgical Performance by Surinamese Lutherans and Ghanaian Methodists in Amsterdam, Liturgia Condenda 26 (Leuven: Peeters, 2011), 2.

24) Klomp, The Sound of Worship, 234-36; cf. 225-30.

25) Van der Leeuw, Sacramentstheologie, 182-90. Van der Leeuw addresses here the lie as a paradoxical circumscription of reality (as in taboo).

26) On the liturgical blessing, cf. G. van der Leeuw, Liturgiek (Nijkerk: Callenbach, 1940), 195.

27) Van der Leeuw, Sacramentstheologie, 319-27; cf. Van der Leeuw, Liturgiek, 170, 185.

28) Willem Marie Speelman, Liturgie in beeld. Over de identiteit van de rooms-katholieke liturgie in de elektronische media (Groningen/Tilburg: Liturgisch Instituut, 2004), 27 (“de mediatie van een medium”).

29) Enchiridion Indulgentiarum, 4th edition 1999, Concessiones 4. Available at vatican.va (http://www. vatican.va/roman_curia/tribunals/apost_penit/documents/rc_trib_appen_doc_20020826_enchiridionindulgentiarum_lt.html).

30) For more serious (partly philosophical) questions regarding time and place in (supposedly) 'live' broadcasts, cf. Speelman, Liturgie in beeld, 39-41. 
More directly related to the question of televised or online eucharist is a remark made by the Pontifical Council for Social Communications in its document The Church and Internet from 2002. There it is stated that

virtual reality is no substitute for the Real Presence of Christ in the eucharist, the sacramental reality of the other sacraments, and shared worship in a flesh-and-blood human community. There are no sacraments on the Internet; and even the religious experiences possible there by the grace of God are insufficient apart from real-world interaction with other persons of faith. Here is another aspect of the Internet that calls for study and reflection. At the same time, pastoral planning should consider how to lead people from cyberspace to true community and how, through teaching and catechesis, the Internet might subsequently be used to sustain and enrich them in their Christian commitment. ${ }^{31}$

A few things are clear from this interesting statement. First, there is openness to further "study and reflection". The text is clear, but does not present itself as the last word on this developing theme. Second, the value of the Internet for the church seems to be seen in its catechetical potential. Third, there is a clear statement about the non-availability of sacramental reality through the Internet. And fourth - and perhaps most importantly, being the positive side of the negative third statement - the document emphasizes not only the importance but the indispensability of "shared worship in a fleshand-blood human community", the "real-world interaction with other persons of faith", and "true community". Here is an affirmation of the fundamental importance of embodied and incarnated faceto-face communication and communion in the Catholic understanding of religion and, especially, the sacraments. Even the choice of words ('flesh-and-blood') is emphatically physical. ${ }^{32}$

Of course, this remains an issue 'under construction'. To what extent is our contemporary understanding of 'unmediated' presence already mixed up with 'mediated' elements?33 I am thinking, for example, of people who are present at an event but who watch the event on the screen of their mobile phone as they film it. That aside, it can be concluded from this section that in order to take part in the eucharist sacramentally, one has to receive communion physically, in an unmediated, not a mediated, relation to the actual celebration.

\section{Locality}

Such a celebration takes place in a particular location. It may be a church or a field. The place may be big or small, impressive or unseemly. We may find ourselves in a geographically large area in which

31) The Church and Internet, Nr. 9. Availabe at vatican.va (http://www.vatican.va/roman_curia/pontifical_ councils/pccs/documents/rc_pc_pccs_doc_20020228_church-internet_en.html).

32) There is no Latin original; the versions in other languages all use the same expression.

33) Cf. Speelman, Liturgie in beeld, 31. 
the eucharist is only celebrated in one place, or we may live in a town with eucharistic celebrations in churches on every corner. Our participation in the eucharist may always happen in the same place, or it may be our custom to join different congregations in various locations. Whatever the circumstances are, one fact is for sure: the eucharistic celebration, in which we participate at this very moment, happens nowhere else than in this particular place.

\subsection{The relevance of a eucharistic ecclesiology of the local church}

This particular place is the epi to auto (coming together 'in one place') from early Christian times until today. ${ }^{34}$ This is the place where the koinōnia, the ekklēsia, becomes tangible. Wherever the eucharist is celebrated, there is communion - there is the church. The same is true of the inverse: there is no church - no parish, no diocese, no ecclesiastical province, no patriarchate, no universal church - without being simultaneously present in this inalienable, irreplaceable locality.

This reality, at once both the most tangible and theological, is the basic assumption of a 'eucharistic ecclesiology'. It has its origins in the New Testament and the Early Church and was rediscovered and systematized in the interrelated biblical, patristic, liturgical, and ecumenical movements, which started in the first half of the twentieth century. Eucharistic ecclesiology - or the closely related 'communion ecclesiology' - has become one of the leading paradigms of Eastern Orthodox, Roman Catholic, Old Catholic, Anglican, and to some degree Protestant and ecumenical ecclesiologies. I have sketched this paradigm several times and have no intention of repeating it here. ${ }^{35}$ I only want to observe that one of the sacramental-theological questions around 'e-eucharist', triggered by the pandemic, seems inevitably to point in the direction of one element of eucharistic or communion ecclesiologies: the essential character of 'the local church'.

Relevant to this article is the ecclesiological question of whether one should give theological priority to the local or the universal church. I subscribe to the concept of simultaneity between the local and the universal church. ${ }^{36}$ This principle of simultaneity between local and universal - in which both the local and the universal cannot remain 'invisible' but need a tangible shape - constitutes a difference between a Congregational and a Catholic interpretation of the importance of the local church.

The church to which I belong, the communion of Old Catholic churches of the Union of Utrecht, has a strong tradition of theological reflection on the importance of the local church within the con-

34) Acts 1:15; 2:1, 2:44, 2:47; 1 Corinthians 11:20; cf. John D. Zizioulas, eucharist, Bishop, Church: The Unity of the Church in the Divine eucharist and the Bishop During the First Three Centuries (Brookline, MA: Holy Cross Orthodox Press, 2001 [Greek original: Athens 1965]), 48-49.

35) Cf. Ploeger, Celebrating Church; Mattijs Ploeger, "Einführung in die Grundgedanken einer eucharistischen Ekklesiologie," Internationale Kirchliche Zeitschrift 105 (2015): 303-14.

36) Here I follow, for example, the Eastern Orthodox John Zizioulas and the Roman Catholic Jean-Marie Roger Tillard. Cf. Christopher Ruddy, The Local Church: Tillard and the Future of Catholic Ecclesiology (New York: Crossroad, 2006), 22-30 (Zizioulas), 99-109 (Tillard). 
text of a Catholic ethos. Peter-Ben Smit and Jan Jorrit Hasselaar point to the fact that this "Old Catholic paradigm ... is often misunderstood as dealing with ecclesiological (and/or related liturgical and canonical) matters only." In reality, working from an emphasis on the local church opens up a whole discourse of locality in relation to - potentially enriching, but also potentially dividing - issues such as ecology, ${ }^{37}$ economy, ${ }^{38}$ and the critical affirmation of the difference of cultures. ${ }^{39}$

In the context of the present article, the relevance of this observation is as follows: the very fact that sacramental presence can only be experienced in a particular place introduces contextual themes such as ecology, economy, and cultural difference into the sacramental experience. ${ }^{40}$ There can be no eucharist apart from locality, but - in a both qualitatively and quantitatively Catholic perspective neither can there be eucharist apart from communion between all localities. Therefore, sacramental experience always takes place in the (creative or destructive) tension between universality (communion) and particularity (otherness)..$^{41}$ There is no such thing as 'abstract' sacramental presence: it is simultaneously local and universal, but both locality and universality must be ‘broken' in order to make room for true sacramental presence. ${ }^{42}$

37) Peter-Ben Smit and Jan Jorrit Hasselaar, “This is My Body: A 'Green' Ecclesiology? Old Catholic Mainstream Theology and the 'Green Theology' of the Ecumenical Patriarchate in Dialogue," Internationale Kirchliche Zeitschrift 107 (2017): 160.

38) Cf., e.g., Franz Segbers, "Globalization as the Context for a Theological and Ethical Understanding of Catholicity," in Globalization and Catholicity: Ecumenical Conversations on God's Abundance and the People's Need, ed. Marsha L. Dutton with Emily K. Stuckey (Bern: Stämpfli, 2010), 147-61.

39) Cf., e.g., Urs von Arx, "Identität und Differenz. Elemente einer christkatholischen Ekklesiologie und Einheitsvision," in Konfessionelle Identität und Kirchengemeinschaft, ed. Helmut Hoping with Jan-Heiner Tück (Münster: LIT, 2000), 109-36; Peter-Ben Smit, “Old Catholic Theology: An Introduction,” Theological Traditions 1, no. 1 (2019): 94-96.

40) This theme is also important in Klomp, "The Sound of Worship," especially regarding the relationship between the concepts 'embodiment of faith in worship', 'incarnational worship', and 'sacramental worship'; cf. above, section 5.2 .

41) The words 'communion' and 'otherness' are an allusion to the work of John Zizioulas; cf. John D. Zizioulas, Communion and Otherness: Further Studies in Personhood and the Church (London: T\&T Clark, 2006). 42) The theme of 'breaking' symbols by 'juxtaposing' them (such as supplication and thanksgiving; presider and congregation; Sunday and the week) is introduced in Gordon W. Lathrop, Holy Things: A Liturgical Theology (Minneapolis, MN: Fortress, 1998), 27-31 and recurs throughout Lathrop's work. What a nonsarcophobic, non-spiritualized and non-individualized liturgical spirituality in relation to earth and locality might look like is explored in Gordon W. Lathrop, Holy Ground: A Liturgical Cosmology (Minneapolis, MN: Fortress, 2003). 


\subsection{The sacrality of locality}

The theological reason why we have to come together in one place is not owing to the fact that some other place would be more sacred than our own home. ${ }^{43}$ In theological terms, there is no such thing as a holy place, apart from the body of Jesus Christ, in whom the holiness of the tabernacle and the temple have become flesh and blood. This body of Christ is present wherever the church (community) and the eucharist (celebration) are present - which can be anywhere. A church building is, theologically speaking, only sacred in a secondary sense: because it is set apart for the body of Christ, understood as both the ecclesial community and the eucharistic celebration. ${ }^{44}$

In this secondary sense, the sacrality of locality does play a part, both anthropologically and theologically. On this topic, liturgical studies in the Netherlands has produced a wealth of books and articles over the last one or two decades. Themes vary from, among other things, pilgrimage (Charles Caspers), monasteries (Thomas Quartier), and musical spaces (Martin Hoondert) to memorials at locations of disaster (Paul Post), the staging of the Passion story in the public domain (Mirella Klomp), and rituality at home (Goedroen Juchtmans). ${ }^{45}$

\subsection{Together in one place: embodied encounter}

But if the indispensability of locality is not primarily grounded in the sacrality of the locality, what is the reason, then, that Christian sacramentality is only possible in the tangible reality of a given place? The necessity of locality is given with our human existence, especially our human being understood as communion. ${ }^{46}$ For the eucharist to be celebrated it is not only necessary that I am in a particular place, but that we are (i.e., we have come together) in a particular place. As much as online or telephone conversations may connect people, this will never be the 'new normal' - a phrase often used in relation to the COVID-19 measures. The anthropological normal is physical encounter.

The Christian theological, liturgical, and mystical tradition - not afraid of its own queerness ${ }^{47}$

\section{3) Cf. Goedroen Juchtmans, "Sacraliteit thuis. Een inkijk in de complexiteit en gelaagdheid van}

hedendaagse rituelen," in Heilig, heilig, heilig. Over sacraliteit in kerk en cultuur, ed. Petra Versnel-Mergaerts and Louis van Tongeren (Heeswijk: Abdij van Berne, 2011), 152-70.

44) Cf. Mattijs Ploeger, "Sacrale stenen. Over de heiligheid van een kerkgebouw" in Ploeger, Geloof dat probeert te begrijpen, 121-24.

45) Here I only want to give an impression of the field by mentioning some names of those who have written more than one publication on the indicated themes. The book series 'Liturgia condenda' (Leuven: Peeters) and 'Meander' (Heeswijk: Abdij van Berne), as well as this Yearbook for Ritual and Liturgical Studies, are the main outlets of these studies.

46) Cf. John D. Zizioulas, Being as Communion: Studies in Personhood and the Church (Crestwood, NY: St. Vladimir's Seminary Press, 1985), 27-65.

47) Cf. Gerard Loughlin, "Introduction: The End of Sex", in Queer Theology: Rethinking the Western Body, ed. Gerard Loughlin (Oxford: Blackwell, 2007), 6-7. 
knows of the daring but apt comparison between the eucharistic and the erotic. An example is the Lutheran hymn Wie schön leuchtet der Morgenstern, written and composed by Philipp Nicolai in 1599, during or shortly after another health crisis, an outbreak of the plague. ${ }^{48}$ The hymn is a love song, largely addressed directly to Jesus Christ, and it includes eucharistic references juxtaposed and intertwined with erotic imagery. Some quotations:

You have taken possession of my heart.

My heart calls you a heavenly flower.

Heavenly manna which we are eating,

I cannot forget you.

Take me friendly in your arm.

He is my treasure (or: darling), I am his bride.

I want to sparkle in steadfast love

with my little Jesus, my stunningly beautiful groom.

Come, you beautiful crown of joy,

don't be long, I'm waiting for you with desire. ${ }^{49}$

The text (not these quotations, but the original) is meant to be printed such that all lines are centered. Printed in this way, each stanza has the graphical shape of a eucharistic chalice. The final line - bleib nicht lange; deiner wart ich mit Verlangen - is like the ending of a love letter. In the context of this hymn, the eucharist is obviously the (physically depicted) meeting in which this longing is fulfilled.

Although a loving partnership can be sustained for a while by writing letters or e-mails, by meeting each other online, by talking to each other over the telephone, the fact remains that sexual 'communion' can only take place in physical reality, having come together in one particular place. Likewise, the unavoidability of locality in sacramental theology is given with the bodily character of the eucharist, which in its turn corresponds with the bodily character of human existence, including the paradigm of human existence: Jesus Christ, who is God incarnate, not metaphorically, not even 'literally', but bodily. A catena of quotations from Louis-Marie Chauvet may underline this:

The disconcerting otherness and holiness of this crucified God never shows itself better than in God's withdrawal, through the Spirit, into human corporality [which takes place in] the sacramen-

48) Cf. the entry by J.W. Schulte Nordholt in Een compendium van achtergrondinformatie bij de 491 gezangen uit het Liedboek voor de kerken (Amsterdam: Van der Leeuw-Stichting, 1978), 413-15.

49) “Du ... hast mir mein Herz besessen" (from verse 1); "Mein Herz heisst dich ein Himmelsblum. ... Himmlisch Manna, das wir essen, deiner kann ich nicht vergessen" (from verse 2); "Nimm mich freundlich in dein Arme" (from verse 4); “er ist mein Schatz, ich seine Braut” (from verse 5); "ich möge mit Jesulein, dem wunderschönen Bräut'gam mein, in steter Liebe wallen” (from verse 6); “komm du schöne Freudenkrone, bleib nicht lange; deiner wart ich mit Verlangen" (from verse 7). Cf. Evangelisches Gesangbuch Nr. 70; Gotteslob Nr. 357. Dutch version (with the intended graphic presentation): Liedboek Nr. 518. The abridged English version (New English Hymnal Nr. 27) has completely lost all eucharistic and erotic overtones. 
tal rites..$^{50}$ The fact that there are sacraments leads us to say that corporality is the very mediation where faith takes on flesh and makes real the truth that inhabits it. ${ }^{51}$ In their significant materiality, the sacraments thus constitute an unavoidable stumbling block which forms a barrier to every imaginary claim to a direct connection, individual and interior, with Christ or to a gnostic-like, illuminist contact with him. ${ }^{2}$

For Chauvet the interpretation of liturgy as "the expression of the human being as a living body" 53 is so fundamental that he can go so far as to suggest that, when believers find that their minds and ideas have lost faith, they still have their bodies to communicate with God. "What else remains for them but their bodies taking in hand what the Church takes up - a little bread and wine"?54

Therefore, Christian sacramentality, especially the celebration of the eucharist, requires the physical movement of coming together in one place. As Gerhards, Kranemann, and Winter rightly say, there should be no such thing as a 'private mass', 55 and as the Vatican document The Church and Internet bluntly but rightly summarizes, "there are no sacraments on the Internet". ${ }^{66}$ Some people - especially some church ministers - may feel desperate about it, ${ }^{57}$ but there is no alternative: for celebrating the eucharist you have to come together (assemble) in one place (locality). Again, this is nothing 'new' in a digital age,,$^{58}$ for the question of whether locality and assembly could be avoided, and the answer that they cannot, is as old as the question of whether you could be sacramentally absolved over the telephone. ${ }^{59}$

This brings us back to the Protestant/Catholic divide of Menke and of Noordmans and Van der Leeuw. ${ }^{60}$ Coming together in one place could only be avoided, if the (phenomenologically) 'Protestant' paradigm would be true: that is, if there would be no trustworthy 'forms' before the eschaton. If everything of importance would be so spiritualized that it vaporizes; if sacramentality would - as a partly understandable over-reaction to too much materialization in medieval piety and perhaps the-

50) Louis-Marie Chauvet, Symbol and Sacrament: A Sacramental Reinterpretation of Christian Existence (Collegeville, MN: The Liturgical Press, 1995 [French original: Paris 1987]), 373. See also 518-31, a section subtitled "The Spirit ... Inscribing Itself into Human Corporality" - perhaps (in another language field) comparable to Menke's concept. See above, section 5.1.

51) Chauvet, 376 (original emphasis); cf. 141, 154-55, 355-56.

52) Chauvet, 153 (original emphasis).

53) Chauvet, 369 (emphasis added).

54) Chauvet, 375.

55) Cf. section 3 .

56) Cf. section 5 .

57) Cf. section 2.

58) Cf. section 1 and 2.

59) A quick search on the Internet reveals numerous blogs (mostly by Roman Catholic authors) who specialize in Q\&As like these.

60) Cf. section 5 . 
ology - not be allowed any 'materiality'; if sacramentality would be understood as 'only' symbolic or 'just' metaphoric; then there would be no embodiment and therefore no need for local particularity. Then there would be no divine/human communion within the anthropological conditions of our human (embodied) existence. Then God would have only met us halfway. An online meeting would suffice.

\section{Conclusion: eucharistic fasting and longing}

Sacramental reality shares all the possibilities and all the limitations of our embodied condition humaine. Possibilities: real encounter, deep communion, attractive beauty, exhilarating joy. Limitations: being irritatingly dependent on practical issues such as embodiment and locality. Where shall we meet? How shall we travel there? Are we physically able to access the place? Are we allowed to go there?

Under COVID-19 measures, the answer to the latter question is no. That is why we, temporarily, cannot sacramentally participate in the eucharist - only spiritually, by virtue of Christ's divine omnipresence. To Christians - especially Christians in 'sacramental traditions' - this results in a period of 'eucharistic fasting', which is not what we want and which can be experienced as spiritually running dry. To take up the eucharistic-and-erotic theme encountered in the previous section, during this period we experience Jesus Christ as a lover who is away for some while. Our meeting with him is temporarily reduced to the 'virtual' domain, which is 'real' but not 'embodied'.

As Marcel Barnard and Mirella Klomp have written in a brief but pertinent contribution to a Dutch newspaper: it is theologically consistent not to bypass this problem, but to endure this pain. ${ }^{61}$ There is no 'new' sacramental theology in times of coronavirus. Being deprived of embodiment and locality of physically coming together in one place - is not the 'new normal' for sacramental Christians or for any human being. It is a period of fasting in multiple ways, a period that has to be endured and overcome in solidarity. In the meantime, this fasting can increase our desire - deiner wart ich mit Verlangen.

Mattijs Ploeger studied theology in Leiden, Utrecht, and Cambridge (UK). He served as a parish priest in the Old Catholic diocese of Haarlem and is now the Dean of the Old Catholic Seminary at Utrecht University, where he teaches systematic theology and liturgy.

Email: mattijs.ploeger@okkn.nl

61) Marcel Barnard \& Mirella Klomp, “Thuis klaarzitten met brood en wijn voor de digitale avondmaalviering? Daarmee slaat u de plank mis,” Trouw, March 26, 2020. 